\title{
Records of horsehair worms (Nematomorpha) in Estonia, with description of three new species from the genus Gordius L.
}

\author{
Andreas Schmidt-Rhaesa ${ }^{\mathrm{a} \varpi}$ and Marko Prous ${ }^{\mathrm{b}}$ \\ ${ }^{a}$ Zoological Museum and Biocenter Grindel, University Hamburg, Martin-Luther-King-Platz 3, \\ 20146 Hamburg, Germany \\ ${ }^{\mathrm{b}}$ Department of Zoology, Institute of Ecology and Earth Sciences, University of Tartu, Vanemuise \\ 46, 51014 Tartu, Estonia \\ ${ }^{凶}$ Corresponding author, andreas.schmidt-rhaesa@uni-hamburg.de
}

Received 15 September 2009, revised 3 November 2009

\begin{abstract}
Except for one record, no species of horsehair worms (Nematomorpha) have been recorded from Estonia. We report here the finding of 35 specimens, 14 of them determined as Gordionus violaceus (Baird, 1853), a widespread European species. Three new species are described. These are Gordius balticus sp. nov. with an angled postcloacal crescent and fine stout bristles on the cuticular surface, Gordius spiridonovi sp. nov. with a row of bristles extending from the posterior tips of the postcloacal crescent onto the tail lobes, and Gordius terminosetosus sp. nov. with longer bristles on the posterior tips of the tail lobes. Additionally, some specimens of the genus Gordius L. with a particular fine structure of the superficially smooth cuticle are reported, but these could not be determined to species level.
\end{abstract}

Key words: Nematomorpha, Gordius, Gordionus, new species, fresh water, Estonia.

\section{INTRODUCTION}

About 300 species of horsehair worms (Nematomorpha) are known, about a third of them from Europe (Schmidt-Rhaesa 1997). The sampling within Europe is nevertheless far from being homogeneous and from some countries no or only a few records are known. This applies to Estonia as well as to the other Baltic states. There is only one brief report of some specimens determined as Gordius aquaticus Linnaeus, 1758 from Lake Võrtsjärv (as lake Wirzjerw) by Mühlen \& Schneider (1920). We report here several records, including the description of three new species of Nematomorpha from Estonia. It can be expected that the species reported here do not represent the entire diversity of species in the region. As only very fragmentary data are known from neighbouring countries, no estimates on the absolute number can be given here.

Adult horsehair worms can be found in fresh water (with the exception of 5 species living in the sea), where they copulate and deposit eggs. From the eggs small larvae (around $100 \mu \mathrm{m}$ ) hatch, which infect hosts. The exact life cycle is 
still unclear (Hanelt et al. 2005), but there is indication for a host change from aquatic to terrestrial hosts. The major development takes place within hosts such as carabid beetles, crickets, or others. Adult worms have been shown to manipulate their hosts, making them enter water so that the nematomorph can emerge (Thomas et al. 2002).

Important for the determination of Nematomorpha species are cuticular characters such as the structure of the body cuticle or cuticular structures in the male posterior end. Representatives of genera such as Gordionus, for example, have spines and bristles in characteristic distribution patterns on the ventral side of the male posterior end (see e.g. Fig. 1C). In contrast, representatives of the genus Gordius are comparably poor in cuticular structures. Characteristic of the genus Gordius is a semicircular cuticular fold, the postcloacal crescent (see e.g. Fig. 2A), but bristles are much finer and fewer compared to Gordionus. Some of such bristles as well as the fine structure of the superficially smooth body cuticle might have been overlooked in earlier investigations that did not use scanning electron microscopy.

Both genera, Gordius and Gordionus, are comparably species-rich, with about 60 and 46 described species, respectively. Both are distributed almost worldwide, but Europe appears to host most species, including abundant ones such as Gordius aquaticus Linnaeus, 1758 and Gordionus violaceus (Baird, 1853).

\section{MATERIALS AND METHODS}

Specimens reported here were collected in different locations in Estonia between 1971 and 2009 (in addition one record from Russia). Investigation of the specimens by scanning electron microscopy (SEM) took place in the Zoological Museum of the University Hamburg, Germany.

Specimens were preserved in ethanol. Pieces of the cuticle and/or the posterior end were prepared for SEM. Pieces were dehydrated in an increasing ethanol series, critically point dried, and coated with gold in a sputter coater. Observation took place using a LEO SEM 1524 under $10 \mathrm{kV}$. Digital images were taken. Specimens are deposited in the Zoological Museum Hamburg ( $\mathrm{ZMH})$, in the Zoological Museum of the University of Tartu (TUZ), and in the personal collection of Andreas Schmidt-Rhaesa. In total, 39 specimens were investigated, 4 of which could not be determined. Four species could be determined to species level, three of these are new to science.

\section{RESULTS AND DISCUSSION}

A total of 39 specimens were investigated. Four specimens could not be determined because they were damaged and are omitted from this report. The remaining 35 specimens belong to four species, three of which are new to science. 
Seven specimens belong to the genus Gordius, but could not be determined to species level.

\section{Gordionus violaceus (Baird, 1853)}

Figure 1

Distribution: Himmiste, Saaremaa, found halfway emerging from a Pterostichus niger (Schaller, 1783) (Carabidae) which was caught on a yellow plate (1웅, collected by M. Prous between 22 June and 3 July 2006); Vellavere, Tartumaa ( $9 \widehat{\partial} \widehat{\partial}$ and one damaged specimen, collected by M. Martin on 2 August 2002); Rägina main ditch, Keskvere, Martna, Läänemaa (1 9 , collected by H. Timm on 24 May 2008); Aa beach, spring in Moldova Village, Virumaa $(1 \hat{\jmath}, 1$, , collected by V. Suitsev on 1-2 July 2006). The specimen from Himmiste is deposited in the Zoological Museum in Tartu (accession number TUZ615004), with an SEM stub in the collection of Andreas Schmidt-Rhaesa (accession number SR 1007); the Vellavere, Keskvere, and Moldova specimens are in the collection of Andreas Schmidt-Rhaesa (accession numbers 1407-1416, 1482, and 1492, respectively).

This species is widespread in Europe (Schmidt-Rhaesa 1997). Characteristic of $G$. violaceus are polygonal structures of the cuticle called areoles, which are surrounded by fine cuticular bristles. It has been shown that the cuticular pattern is quite variable, including various amounts of fusions of the areoles, restricting the interareolar bristles to small patches (Schmidt-Rhaesa 2001). The Estonian specimens show different degrees of the fusion of areoles. In the female from Himmiste and the female from Keskvere, polygonal areoles are clearly isolated from each other (Fig. 1A), while in the males from Vellavere and both specimens from Moldova, several degrees of fusion can be observed (Fig. 1B, D). The posterior end of the male specimens corresponds to the previous characterizations of this species (see e.g. Villalobos et al. 1999; Schmidt-Rhaesa 2000, 2001; Schmidt-Rhaesa \& Kristensen 2006; Schmidt-Rhaesa \& Zaenker 2006 for SEM documentations) in having paired rows of cuticular bristles anterior of the ventral cloacal opening, bristles surrounding the cloacal opening and short spines on the ventral side of the tail lobes (Fig. 1C, E). In a distance about $0.9 \mathrm{~mm}$ anterior of the cloacal opening on the ventral side, elongate structures described as adhesive warts are present (Fig. 1F). These extend at least $18 \mathrm{~mm}$ in anterior direction.

\section{Gordius balticus Schmidt-Rhaesa, new species}

Figure 2

Holotype: South Estonia (exact location unknown), in rainwater barrel (1§, the collector according to the label is 'Elli', year 2008). Deposited in the Zoological Museum in Hamburg (accession number ZMH V13268), an SEM stub with a piece of cuticle from the holotype is deposited in the Zoological Museum in Tartu (accession number TUZ615007). 

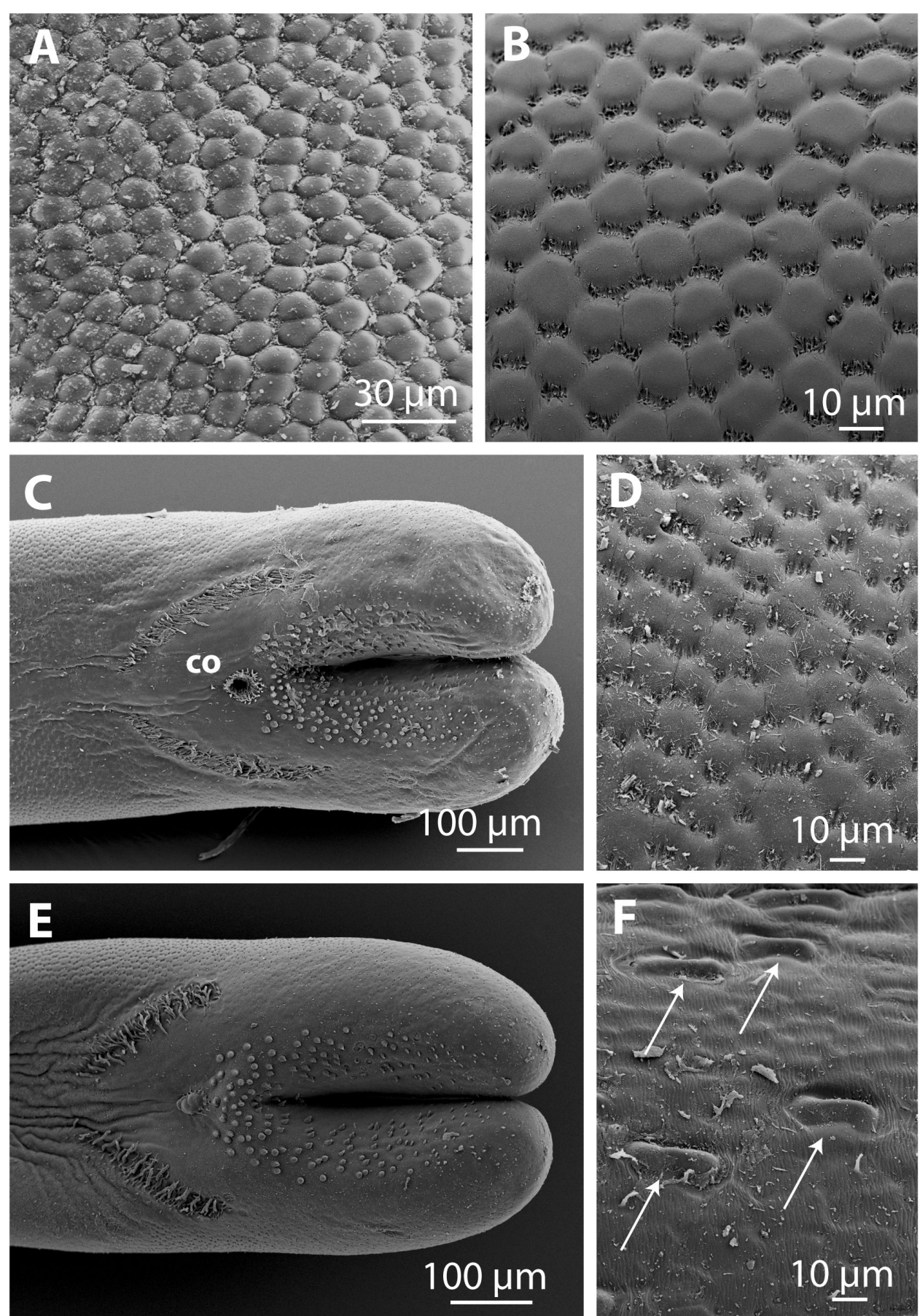

Fig. 1. Gordionus violaceus, SEM. A, Cuticle of the Himmiste female. B, Cuticle of a Vellavere male. Areoles are partly fused. C, E, Ventral view on the posterior end of two male specimens showing cloacal opening (co), paired rows of bristles anterior, and spines posterior of the cloacal opening. D, Cuticle in the Moldova male. F, Adhesive warts (arrows) in the ventral region anterior of the cloacal opening. 
Paratype: Rainwater collection container in Suurküla, Häädemeeste, Pärnumaa (19, collected by M. Looring on 23 August 2006). Deposited in the Zoological Museum in Hamburg (accession number ZMH V13288).

Further material: $1 \delta^{\lambda}$ sampled together with the paratype. Deposited in the collection of Andreas Schmidt-Rhaesa (accession number 1490).

Etymology: The name refers to the Baltic region.

The male holotype measures $260 \mathrm{~mm}$ in length and $0.8 \mathrm{~mm}$ in diameter, the female paratype is $325 \mathrm{~mm}$ long and has a diameter of $1.1 \mathrm{~mm}$. The additional male specimen measures $275 \mathrm{~mm}$ in length and $0.75 \mathrm{~mm}$ in width. The body colour varies from dark brown (holotype) to medium brown (additional male) and light brown (paratype), a few white spots are present in both males. The posterior end of the males contains two lobes, which are about $440 \mu \mathrm{m}$ long. The tail lobes of both specimens are concave (Fig. 2A, B); this may be a product of desiccation or shedding of gametes, because the entire posterior end shows some artificial folding.

On the ventral side of the posterior end is an angled postcloacal crescent (Fig. 2A). The cloacal opening is covered by an artificial object, but may be slightly oval. Several fine bristles can be observed in the entire posterior region. In the holotype a number of short (up to $2 \mu \mathrm{m}$ ) processes are present in the posterior end. They originate in shallow circular pits (Fig. 2E). These processes are short and do not taper like bristles. They are called here stout bristles. Such processes were not found in the additional male. Around the cloacal opening and extending onto the tail lobes, the cuticle is structured into barely visible polygonal areoles (Fig. 2G), otherwise the cuticle is smooth.

In the main part of the body, the cuticle is smooth (Fig. 2C), but high magnifications reveal a particular substructure. The cuticle is structured into numerous branching and fusing cords of about $2 \mu \mathrm{m}$ width (Fig. 2D, F). In the holotype, it appears in some regions as if there is an outer layer that is partly shedding in the form of roughly polygonal patches (Fig. 2D). The cords are not present in the additional male.

Discussion: Unfortunately, the information concerning the holotype (i.e. exact location, collector, and date) is lacking or not very detailed. However, as this specimen showed the clearest characters for this species, we decided to designate it as the holotype.

The character combination of an angled postcloacal crescent and bristle-like structures on the cuticle is not present in the other Gordius species described. Therefore, we describe this as a new species. The presence of short processes in the posterior end of the holotype but lacking in the additional male is a further characteristic of this species.

The cuticle appears smooth at first sight, but has a particular substructure. In very few other species the cuticle has been investigated using such high magnification. Therefore we cannot compare the cuticular fine structure at present 
A. Schmidt-Rhaesa and M. Prous
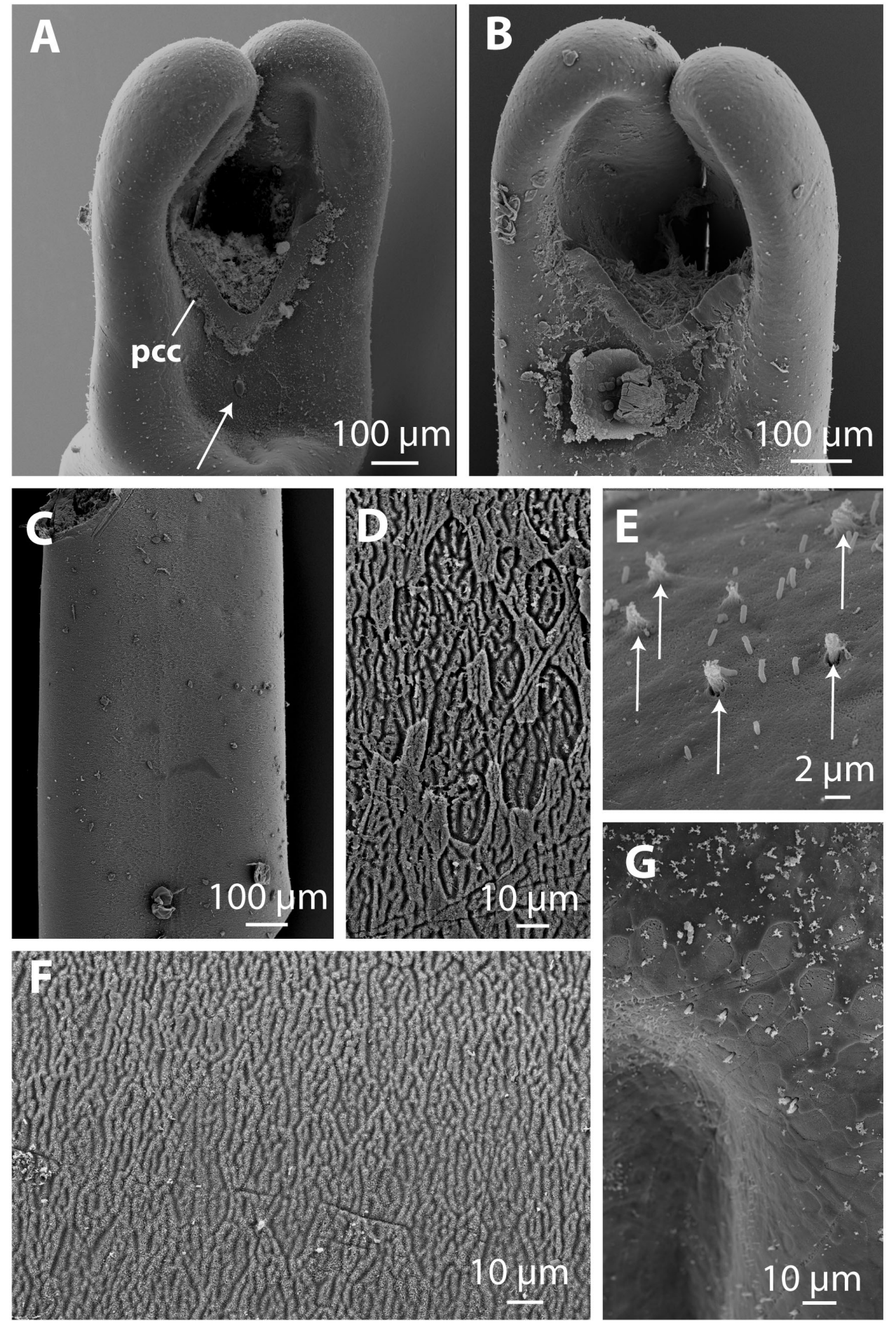
with other species. It should, however, be checked in the future whether the fine cords of the cuticle may be another character characteristic of G. balticus.

The additional male differs from the holotype in the absence of the short processes and in a different cuticular fine structure. It cannot be excluded that it does not belong to G. balticus, but as it shows the other typical characters (angled postcloacal crescent, insignificant polygonal patterning in the posterior end, bristles in the posterior end), we assume that it belongs to this species.

\section{Gordius spiridonovi Schmidt-Rhaesa, new species}

Figure 3

Holotype: Lake Peipsi (about $\left.58^{\circ} 40^{\prime} \mathrm{N}, 27^{\circ} 30^{\prime} \mathrm{E}\right)\left(1 \hat{0}^{\hat{\prime}}\right.$, collected by an unknown person on 9 June 1980). Deposited in the Zoological Museum in Hamburg under accession number ZMH V13286.

Paratype: Russia: Udoha River (tributary of the Shelon River), near Borovit, Pskov Region (10̂, collected by T. Timm on 7 July 1971). Deposited in the Zoological Museum in Hamburg under accession number ZMH V13287.

Further material: Maadevahe Stream on Saaremaa Island $\left(58^{\circ} 23.35^{\prime} \mathrm{N}\right.$, $22^{\circ} 56.78^{\prime}$ E) (19, collected by H. Timm on 5 April 1989); Alevijärv, Valgamaa $\left(1{ }^{\lambda}, 1\right.$, collected by T. Timm on 12 July 1978); Lake Parika, Viljandimaa (4 individuals including 19 , collected by an unknown person

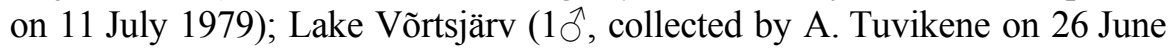
2002). Specimens are deposited in the collection of Andreas Schmidt-Rhaesa (accession numbers 1484, 1486a, 1486b, 1487, 1491, respectively).

Etymology: The name honours Sergej Spiridonov (Moscow, Russia) for his contributions to nematomorph knowledge.

The four male specimens range in length from 135 to $315 \mathrm{~mm}$ (holotype $255 \mathrm{~mm}$, paratype $135 \mathrm{~mm}$ ), their width is between 0.4 and $0.6 \mathrm{~mm}$ (holotype 0.5 , paratype 0.4 ). The three females measure 240,260 , and $280 \mathrm{~mm}$ in length and $0.5,0.5$, and $0.9 \mathrm{~mm}$ in diameter, respectively. Most specimens are medium brown in colour, but both specimens from Alevijärv are dark brown. A white anterior cap and a dark collar are always present. Males have white spots on their cuticle. Darker ventral and dorsal longitudinal lines are present in some specimens but were not observed in others.

Fig. 2. Gordius balticus n. sp., SEM. A, Ventral view on the posterior end of the holotype showing the angled postcloacal crescent (pcc) and the position of the cloacal opening (arrow). B, Posterior end of the male from Suurküla, ventral view. C, Cuticle appears smooth under low magnification. D, Higher magnification reveals fine structure and shedding of polygonal patches (holotype). E, Stout bristles on the cuticle (arrows), between bristles are bacteria. F, Cuticle from female paratype. G, Polygonal areoles in the vicinity of the cloacal opening (holotype). 


\section{A. Schmidt-Rhaesa and M. Prous}
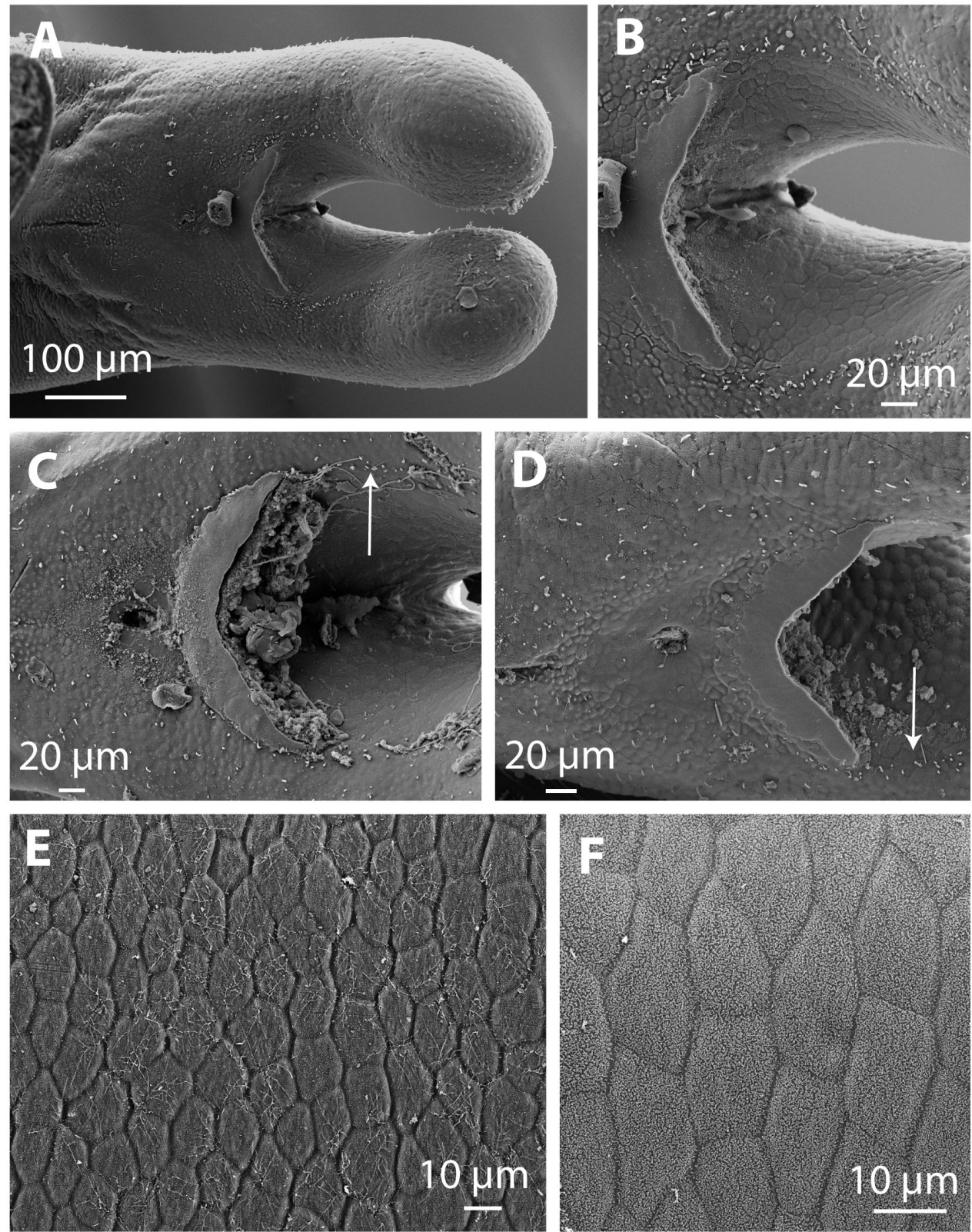

Fig. 3. Gordius spiridonovi n. sp., SEM. A-D, Ventral view on the posterior end of the males, showing the line of bristles originating from the posterior ends of the postcloacal crescent (arrows) (A, B, holotype; C, Maadevahe male; D, paratype). E, F, Cuticular pattern from paratype (E) and holotype $(\mathrm{F})$. 
The male tail lobes are shorter than twice their diameter. The postcloacal crescent is semicircular. It has a width of about $170 \mu \mathrm{m}$, which is about $50 \%$ of the width of the posterior end at the level of the crescent. The tail lobes branch directly behind the postcloacal crescent. The arms of the crescent extend slightly onto the tail lobes. The cloacal opening is slightly oval. Several fine bristles are present on the ventral side of the posterior end. Several bristles are concentrated in a line that runs from the posterior tip of the postcloacal crescent onto the tail lobes, with a slight curve to their inner side. The density of bristles in this line may vary and in some specimens assigned to this species it is not as distinct as in the holotype.

In the main part of the body, the cuticle is structured into polygonal areoles. In some cases, few areoles appear to merge along one side, but the borders between areoles remain always visible. Polygonal areoles are also present in the entire posterior end, with the exception of a small smooth region around the cloacal opening.

Discussion: The arrangement of bristles in the posterior end forming a line on the tail lobes occurs in few species of the genus Gordius. In G. borisphaenicus Spiridonov, 1984 from the Ukraine, a row of bristles leads from the end of the postcloacal crescent to a field of spines, which are concentrated on the inner side of the tail lobes, about halfway between the point of bifurcation and the tips (Spiridonov 1984). In two yet undescribed species from Germany and Switzerland, a broad field or a narrow row of bristles is present posterior of the tips of the postcloacal crescent (Schmidt-Rhaesa in prep.), but both species differ from the species described above. Therefore, the character composition is new and justifies the description as a new species.

Females do not possess the characteristic features of the males but were assigned to this species on the basis of a similar cuticular pattern.

\section{Gordius terminosetosus Schmidt-Rhaesa, new species}

Figure 4

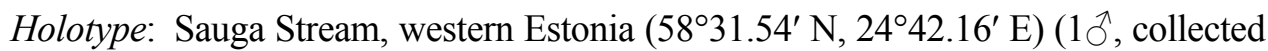
by H. Timm on 16 August 1993). Deposited in the Zoological Museum in Hamburg under accession number ZMH V13279.

Etymology: The name refers to the characteristic long bristles at the terminal end of the tail lobes.

The single male specimen measures $130 \mathrm{~mm}$ in length and $0.5 \mathrm{~mm}$ in diameter. The body colour is light brown, white spots are present on the cuticle. In the anterior end a white tip is present, but a dark collar is only very weakly visible. Dark ventral and dorsal longitudinal lines are diffuse, but present. 


\section{A. Schmidt-Rhaesa and M. Prous}
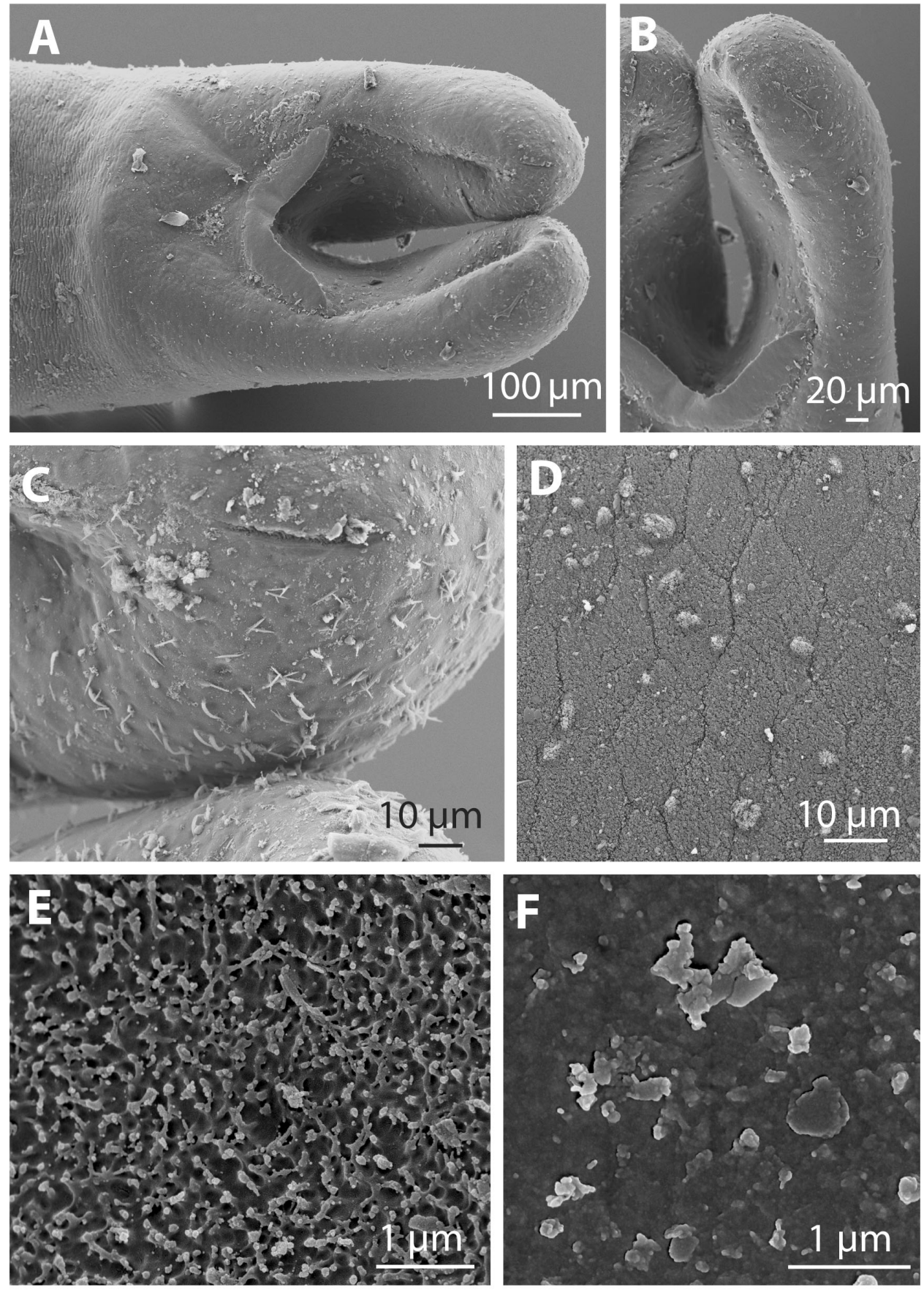

Fig. 4. A-D, Gordius terminosetosus n. sp., SEM. A, B, Ventral view on the posterior end. $\mathrm{C}$, Detail showing long bristles on the tips of the tail lobes. D, Cuticular pattern with polygonal areoles. E, F, Gordius sp. E, Cuticle fine structure in the undetermined Gordius female from Peedu. $\mathrm{F}$, Cuticle fine structure in the Erala female. 
The male tail lobes are about twice as long as their diameter. The inner side of the tail lobes is concave. The postcloacal crescent is quite broad (about $220 \mu \mathrm{m}$, which is about $62 \%$ of the width of the posterior end at the level of the crescent) and semicircular. The tail lobes branch directly behind the postcloacal crescent. The arms of the crescent extend slightly onto the tail lobes. The exact form of the cloacal opening could not be observed. Several fine bristles are present on the ventral side of the posterior end. They have the largest density on the inner side of the tail lobe tips, where they are up to about $8 \mu \mathrm{m}$ long.

In the main part of the body, the cuticle is structured into barely visible polygonal areoles. In the ventral region anterior of the posterior end, areoles become slightly more prominent. Areoles are lacking in the region around the cloacal opening.

Discussion: The presence of long bristles at the posterior tip of the tail lobes has not been described from other species in the genus Gordius and is therefore regarded here as a new character.

\section{Undetermined Gordius specimens}

Material: Erala Village, Tartumaa $(1 \propto$, collected by S. Umarov on 30 September 2002; Zoological Museum in Tartu, accession number TUZ615005; SEM stub in the collection of Schmidt-Rhaesa under number SR 1006); pond at Peedu, Tartumaa (1 $\odot$, collected by Mikk Heidemaa on 2 August 2002; Zoological Museum in Tartu, accession number TUZ615006; SEM stub in the collection of Schmidt-Rhaesa under number SR 1406); delta of the Kasari River, Läänemaa $(4 \hat{\jmath} \hat{\jmath}$, one of which was investigated in detail; collected by A. Tuvikene on 4 June 1992; in the collection of Schmidt-Rhaesa, accession number 1485); pond in Võuküla, Räpina Municipality, Põlvamaa (1+, collected by T. Kama on 11 April 2009; in the collection of Schmidt-Rhaesa, accession number 1494).

The male specimens measure between 230 and $285 \mathrm{~mm}$ in length and have a diameter of $0.5 \mathrm{~mm}$. Their body colour is medium brown, white spots on the cuticle and darker dorsal and ventral lines are present additional to the white anterior cap and a dark collar. Females measure $385 \mathrm{~mm}$ (Peedu), $400 \mathrm{~mm}$ (Räpina), and $555 \mathrm{~mm}$ (Erala), their width is $1 \mathrm{~mm}, 0.95 \mathrm{~mm}$, and $1.1 \mathrm{~mm}$, respectively. The body colour is medium brown (Erala and Räpina specimens) or yellowish white (Peedu). A white cap and dark collar are present, but white spots or dark longitudinal lines are absent.

The cuticle is smooth in all specimens, but higher magnifications reveal differences in the fine structure. While the cuticle from the Erala female is irregularly uneven (Fig. 4F), in all other specimens it is structured into finest processes and ridges (Fig. 4E).

A cuticle appearing as smooth under moderate magnifications is known only from the genus Gordius, therefore the specimens must belong there. Unpublished observations on several Gordius specimens with a superficially smooth cuticle 
show that the fine structure varies, but this is hardly documented. Additionally, it is not known how much of this fine scale structuring is due to mechanical or chemical erosion. For these reasons, these specimens are reported here as belonging to the genus Gordius, but are not further determined to species level.

\section{ACKNOWLEDGEMENTS}

We thank Dr. Mikk Heidemaa (University of Tartu) and Dr. Mati Martin (University of Tartu) for useful comments and suggestions on the manuscript. Many thanks go to Dr.Sci. Tarmo Timm (Estonian University of Life Sciences) for sending the specimens from the Centre for Limnology together with additional information. Ms. Ann Kraut (University of Tartu) is thanked for identifying the carabid host of one of the specimens of Gordionus violaceus. The study was partly supported by the Estonian Ministry of Education and Research (project 0180122s08) and the European Union through the European Regional Development Fund (Centre of Excellence FIBIR).

\section{REFERENCES}

Hanelt, B., Thomas, F. \& Schmidt-Rhaesa, A. 2005. Biology of the phylum Nematomorpha. $A d v$. Parasitol., 59, 243-305.

Mühlen, M. von zur \& Schneider, G. 1920. Der See Wirzjerw in Livland. Biologie und Fischerei. Arch. Naturk. Ostbalt., 14, 1-38.

Schmidt-Rhaesa, A. 1997. Nematomorpha. In Süßwasserfauna Mitteleuropas (Schwoerbel, J. \& Zwick, P., eds), pp. 1-124. Gustav Fischer Verlag, Stuttgart.

Schmidt-Rhaesa, A. 2000. Rasterelektronenmikroskopische Untersuchungen an Gordionus violaceus und Gordius elongiporus n. sp. (Nematomorpha) aus Niederösterreich. Linzer Biol. Beitr., 32, 455-461.

Schmidt-Rhaesa, A. 2001. Variation of cuticular characters in the Nematomorpha: studies on Gordionus violaceus (Baird, 1853) and G. wolterstorffii (Camerano, 1888) from Britain and Ireland. Syst. Parasitol., 49, 41-57.

Schmidt-Rhaesa, A. \& Kristensen, P. 2006. Horsehair worms (Nematomorpha) from the Baltic Island Bornholm (Denmark), with notes on the biology of Gordius albopunctatus. J. Nat. Hist., 40, 495-502.

Schmidt-Rhaesa, A. \& Zaenker, S. 2006. Saitenwürmer (Nematomorpha) aus hessischen Höhlen, Bergwerksstollen und Quellen, mit der Beschreibung einer Abnormalität bei einem Individuum. Hessische Faunistische Briefe, 24, 65-77.

Spiridonov, S. E. 1984. Two new Nematomorpha species of the family Gordiidae. Proc. Zool. Inst. USSR Acad. Sci., 126, 97-101 (in Russian).

Thomas, F., Schmidt-Rhaesa, A., Martin, G., Manu, C., Durand, P. \& Renaud, F. 2002. Do hairworms (Nematomorpha) manipulate the water-seeking behaviour of their terrestrial hosts? J. Evol. Biol., 15, 356-361.

Villalobos, L. C. de, Ribera, I. \& Downie, I. S. 1999. Hairworms found in Scottish agricultural land, with descriptions of two new species of Gordionus Müller (Nematomorpha: Gordiidae). J. Nat. Hist., 33, 1767-1780. 


\title{
Andmeid Eesti jõhvusside (Nematomorpha) kohta koos kolme uue liigi kirjeldusega perekonnast Gordius L.
}

\begin{abstract}
Andreas Schmidt-Rhaesa ja Marko Prous
Peale ühe leiuteate pole Eestist ühtki jõhvussi liiki (Nematomorpha) seni registreeritud. Artiklis on käsitletud 35 isendit, kellest 14 on määratud Euroopas laialt levinud liigiks Gordionus violaceus (Baird, 1853). On kirjeldatud kolme uut liiki. Need on Gordius balticus sp. nov. nurkja kloaagitaguse struktuuri ja peente tugevate harjastega kutiikulal, Gordius spiridonovi sp. nov. kloaagitaguse struktuuri posterioorsetest tippudest pärasagaratele ulatuva harjaste reaga ning Gordius terminosetosus sp. nov. pikemate harjastega pärasagarate posterioorsetel tippudel. Lisaks on käsitletud isendeid perekonnast Gordius L., kelle näiliselt sile kutiikula on eriti peene struktuuriga, kuid keda pole õnnestunud liigini määrata.
\end{abstract}

